\title{
The Roles of Military and Civilian Forces in Domestic Security
}

\author{
Rasmus Dahlberg and Anja Dalgaard-Nielsen
}

\section{Contents}

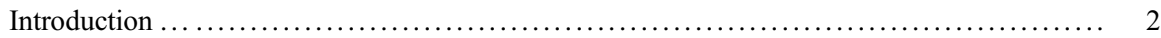

Introducing the Research Field .......................................... 3

Drivers of the Involvement of Armed Forces in Domestic Security ................. 4

Military Involvement in Domestic Security: Risks ............................. 6

What and How to Study? ................................................ 9

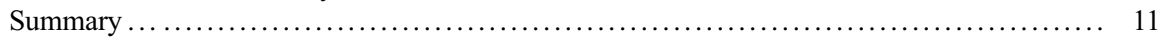

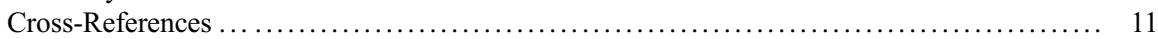

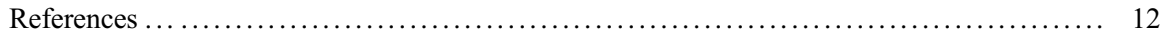

\begin{abstract}
This chapter addresses the intersection of military and civilian forces in domestic security, taking its point of departure in the recent deployment of troops in antiterror operations in France and a general shift toward stronger involvement of military forces in what have traditionally been police matters. We introduce the research field beginning with classic sociological texts from the 1950s with an emphasis on the scholarly debate from around 2000. Building on the literature we discuss different drivers behind the shift toward militarization of domestic security affairs. Finally, we present a variety of suggestions for approaches to further research in the field.
\end{abstract}

R. Dahlberg $(\square)$

Institute for the Study of Military History, Culture and War/Royal Danish Defense College, Copenhagen, Denmark

e-mail: rada@fak.dk
A. Dalgaard-Nielsen
Institute for Strategy/Royal Danish Defense College, Copenhagen, Denmark
e-mail: andn@fak.dk

(C) The Author(s) 2020 


\section{Keywords}

Civil-military relations $\cdot$ Para-military policing $\cdot$ Constabulary force $\cdot$ Domestic security $\cdot$ Terrorism $\cdot$ Risk $\cdot$ Societal security $\cdot$ Gendarmerie

\section{Introduction}

In January 2015, the French government launched one of the largest military operations since the Second World War. It did not concern an international conflict or the protection of French territorial integrity against an external enemy. Rather, Opération Sentinelle, involving at one point up to 10,000 troops, entailed the deployment of soldiers to guard tourist sites and patrol the streets of French cities against an obdurate terrorist threat that may come from within or from without. France is, however, not the only Western country to have expanded the use of armed forces for domestic purposes in recent years (Schack 2016; Johansen 2017). Whether spurred by perceived threats from terrorism, organized crime, irregular immigration, or lawlessness in the wake of natural disasters, numerous countries have moved toward greater involvement of the armed forces in domestic security, including support for national and local police forces.

Police and military are usually understood as two separate entities with different tasks and logics. While police forces traditionally have been responsible for internal security and the upholding of public order, the military's primary task has been defending the territory and interests of a state against foreign enemies. However, these definitions, building on a strict separation of state and societal security, have been questioned by a group of leading scholars in the field (Easton et al. 2010). From the earliest days of state-building, chieftains and kings needed armed forces to provide external as well as internal security. In the Middle Ages, constables and marshals were tasked with keeping order in the armies and garrisons, and gradually their jurisdiction was expanded to also include the general public. Modern policing, with its etymological roots in the French word for "public order," originates from seventeenth- and eighteenth-century France and England, when the first permanent, uniformed police forces were created. During the Age of Absolutism, however, the kings of Europe did not distinguish between military and civilian forces when providing domestic security. Only after the democratic revolutions and the process of rapid urbanization in the middle of the nineteenth century the responsibilities for external security (military) and internal security (police) in general became separated (McCrie 2006). From a broad historical perspective, the strict separation of police and military is thus a modern invention that presents itself more as a temporary phenomenon than a fundamental condition.

In this chapter, we first outline the key scholarly positions as to what drives the apparent recent increase in military involvement in domestic security, primarily from a Western European perspective, but with digressions and comparisons to other parts of the world. We then discuss which risks it involves when seen from a military and from a civilian perspective. Finally, we point to areas where more research is needed 
to understand and asses the drivers and implications of the use of armed forces in domestic security.

\section{Introducing the Research Field}

Relations between civilian and military forces have traditionally been studied mostly by US scholars beginning with political scientist Samuel Huntington's seminal work The Soldier and the State (1957). However, Huntington's aim was to analyze civilian control of the military, which in his opinion should be objective to allow professional soldiers autonomy within a clearly defined framework, and his book did not specifically address the question of armed forces in policing roles. Sociologist Morris Janowitz' notion of "constabular force," presented in The Professional Soldier (1960) which was written as response to Huntington's book, on the other hand proposed a civic-republican theory encouraging a participatory approach that involved both the civil and military society. Janowitz claimed that Western armed forces were undergoing a process of "constabularization" by using limited force to reestablish stability quickly in small-scale conflicts, thus creating military forces resembling police forces in order to avoid total nuclear war. The dual roles of warring and policing remained, however, in Janowitz's conception, roles to be acted out internationally, where the "constabulary officer" could apply violence in tightly controlled and limited circumstances, retaining close links with the society he was protecting (for a post-Cold War discussion of Huntington and Janowitz' contributions, see Feaver 1996 or Burk 2002).

Recently, scholars have noted a process of convergence, not just between the roles and tasks but also between the organizations, approaches, and cultures of military and civilian forces in Western European countries (Bigo 2000; Campbell and Campbell 2010; Dunlap 1999). Internationally, the argument goes, armed forces are called upon to deter potential state adversaries, but also to engage in counterinsurgency and stabilization missions with an eye to building local institutions capable of and willing to cooperate in the management of transnational problems like terrorism, organized crime, and irregular immigration. Force must be used sparingly and precisely in order not to undermine local support and the legitimacy of local partners. Domestically, the argument continues, military forces take up more security tasks, while non-military forces (police, border guards, etc.) are increasingly using military equipment and tactics. Policing is also increasingly intelligence-led and aimed at predicting and preventing crime, thus mimicking military approaches. The result, according to these scholars, is an increased cooperation between institutions that are in a number of respects different (Dunlap 1999, p. 220).

Not everyone agrees, however, that this trend is significant and/or truly new (Weiss 2011, p. 400). Several scholars call for additional country case studies guided by clear concepts and definitions, e.g., is it possible to register convergence in norms, culture, approach, tactics, tasks, etc. to arrive at a more finely grained understanding of whether and where increased cooperation is happening (Kalkman 2019, p. 4; Weiss 2011, p. 402). A common denominator in the literature, however, is that a 
renewed and reinforced threat from terrorism, especially since the early 2000s, has driven police and military toward each other. Though one may debate whether the expansion and proliferation of domestic roles of armed forces represents a qualitatively new or simply a quantitative development, there is broad scholarly consensus that the trend is real: Armed forces increasingly guard potential targets of terrorist attack, patrol the streets, and assist in emergency response or in countering organized crime within national borders (Clarke 2013, 69; Kalkman 2019, p. 2). Parallel with developments in domestic security, armed forces are also becoming increasingly involved in disaster relief and response, challenging the Oslo guidelines on the use of military and civil defense assets for such purposes published by UN OCHA in 1994, which stated that military foreign aid should be considered a last resort. American military forces were heavily engaged in response and relief efforts during the hurricane disaster in New Orleans in 2005 and the Haiti Earthquake in 2010, and the US Armed Forces also assisted Japan when an earthquake generated a tsunami resulting in a nuclear disaster in 2011 (Fisher 2011).

One version of civil-military entanglement is gendarmerie (military units with constabulary powers), embodying the convergence of civilian and military use of force in a single unit. The French Maréchaussée was established in 1720 for territorial control and renamed the Gendarmerie Nationale in 1791 during the French Revolution. The gendarmes, who have traditionally been responsible for law and order in the rural parts of France, even if they are formed and trained as military units, reside under the Ministry of the Interior with close connections to the Ministry of Defence, and the gendarmes abide to military law (Gobinet 2008). Apart from the Gendarmerie, France also has a strong tradition for using regular armed forces for internal security purposes. In 1947, 10,000 soldiers, including paratroopers from French Indochina, were inserted to crack down on Communist protesters at the Renault factories (Stevnsborg 2018). The Algerian struggle for independence in the 1950s and 1960s also saw French use of military force to ensure internal security. This created a tradition in France for strong police-military entanglement, governed by a complex set of laws and regulations, with a high degree of governmental freedom and few parliamentary restraints. Another version of civil-military entanglement is the para-military state security organizations traditionally associated with Soviet bloc during the Cold War and the successors hereof. While civilian, often under the Ministry of Interior or Security, these organizations employed military discipline, tactics, and logic, although applied to internal security threats rather than external. Some scholars argue that today's semi-state security forces such as the "Wagner Group" derive from this tradition (Marten 2019).

\section{Drivers of the Involvement of Armed Forces in Domestic Security}

Scholars from different academic traditions - political science, legal, historical, organizational, and critical - have pointed to a variety of drivers of the increased military involvement in domestic policing tasks (Edmunds 2006, p. 1061; Kalkman 2019, p. 2). 
For the sake of overview, we classify them into (1) exogenous macro-level changes in the international threat and risk environment; (2) domestic political, economic, institutional interests, which gain from framing problems as security threats that call for a militarized response; and (3) societal and organizational attempts to cope with complex challenges, leading to organizational "mimicry" whereby armed forces and police forces increasingly look and behave alike.

\section{Changing Risk Environment}

The first group of scholars mainly emphasizes exogenous and functional drivers, such as evolving and growing transnational problems like terrorism, organized crime, irregular immigration, or natural disasters growing more frequent and severe due to climate change. These challenges, the argument goes, transcend borders and threaten to overwhelm police forces and civilian authorities and capabilities. The nature of the current threat and risk environment therefore calls for a greater level of military-police cooperation and for the military to assist the police and other civilian authorities with more tasks (Kalkman 2019, p. 2; Schnabel and Krupanski 2012, p. 64). The military, they argue, possesses special capabilities and readily available manpower, which can be put to use in exceptional circumstances (Schnabel and Krupanski 2012, pp. 39-40). Policymakers and official policy documents argue along similar lines - deploying military personnel and assets in support of the police is depicted as a natural, reasonable course of action, which reflects current threats and ensures efficient use of overall national capabilities and resources (Nielsen and Domino 2018, p. 4).

\section{Interest Politics}

Other scholars have instead emphasized the domestic, political, societal drivers of the increased involvement of armed forces in domestic security. In the wake of the Cold War, they point out, armed forces, defense industries, conservative politicians, etc. needed new raison d'êtres and sources of income. Getting involved in internal security provided a way for armed forces to demonstrate their utility and legitimize their budgets (Campbell and Campbell 2010, p. 337; Clarke 2013, p. 80). Problems like international terrorism, organized crime, and illegal immigration may be real, these scholars argue, but it is important to pay attention to how the practice of European security agencies frame these phenomena as security threats that warrant new responses, among them the participation of armed forces in maintaining internal security (Bigo 2000, p. 178).

\section{"Institutional Mimicry"}

Finally, some scholars point to organizational processes whereby organizations "mimic" other, apparently successful organizations and thus become increasingly alike. Such processes might happen in situations of high complexity and absence of agreed-upon measures of success vis-à-vis the organization's performance. Mimicking other successful and legitimate organizations, an organization "borrows" from those organizations' legitimacy. While these scholars are not necessarily uncritical of the increased involvement of armed forces in domestic security, they do not see this 
as part of an overarching malign scheme on part of conservative politicians and security agencies. It results, according to this argument, from improvisational, ad hoc organizational attempts to navigate a complex risk environment while preserving organizational legitimacy (Campbell and Campbell 2016, p. 348).

\section{Military Involvement in Domestic Security: Risks}

While a majority of Western citizens express trust in their armed forces and, for example, in the case of France, overwhelmingly support the troops' presence in the cityscape, critical voices from within and outside of the armed forces have been raised (Clarke 2013, p. 80; Chrisafis 2016). While trust in the armed forces is generally high in most Western democracies, the current trend of domestic military involvement, critics argue, risks undermining the combat readiness and morale of troops as well as civil liberties and, ultimately, at least in less well-established democracies, civilian control of the armed forces (Johnson 2018). This section expands on the risks when seen from a military and civilian perspective, respectively.

\section{Reputation, Morale, and Combat Readiness}

On May 20, 1997, a group of US Marines accidentally shot to death an American high school student during an anti-drug patrol along the US-Mexican border. An investigation by the US House of Representatives left a number of questions about the exact reason for the shooting open. However, it did point out that the Justice Department, which had requested the patrol, failed to ensure that the Marines were trained for law enforcement tasks or briefed on local conditions. The shooting led to local protests and to an end to the use of military forces for anti-drug patrolling along the border (Suro 1998).

On November 13, 2015, a group of terrorists attacked the concert hall Bataclan in Paris. Though lightly armed police and more heavily armed soldiers arrived within a short time, the soldiers rejected the police officers' request to help move into the concert hall, arguing that they were not authorized to do so. It took another $30 \mathrm{~min}$ for special police units to arrive and initiate the hostage rescue operation (Schack 2016, p. 4). This incident highlights the potential reputation risks to the armed forces once involved in domestic policing, even if French citizens overwhelmingly approve of the massive presence of soldiers in the cityscape (Clarke 2013, p. 80; Chrisafis 2016). Excessive use of force or a standoffish attitude in a moment of crisis could conceivably both be damaging and chip away at an otherwise favorable public image of the armed forces. It highlights the importance of a clear legal framework, clear rules of engagement, and appropriate training and preparation of troops but also, as in the Bataclan incident, the ability to understand and react flexibly to extraordinary situations in tight coordination with the police.

Guard duty, riot control, and patrolling in a domestic context may undermine morale and make recruitment to the armed forces more difficult (Dunlap 1999, p. 224). Soldiers sign up for warfighting and international operations, not for domestic tasks, the argument goes. Domestic counterterrorism tasks, however, 
may conceivably be perceived as highly meaningful to many troops, at least in the months following a major terrorist attack, where a heightened sense of patriotism can often be registered in the affected country. There is currently a lack of systematic research into how the members of armed forces perceive different domestic tasks in terms of importance and meaningfulness and therefore no definitive answer as to their impact on morale (Kalkman 2019, p. 5).

Another risk, pointed out by critics, is the loss of training time, combat readiness, and a deterioration of the troops" "savoir-faire" (Gen. Vincent Desportes, cited in Chrisafis 2016; Dunlap 1999, p. 223). Not all agree, however, that domestic tasks make the armed forces less effective internationally. Wass de Cwege (2006, p. 15) argues that the need to flexibly shift between different roles is indispensable and integral to any armed force with the ambition to match the current diverse and unpredictable threat environment and that the track record of the US Armed Forces from the 00s show that they have the ability, at least when properly trained and led, to do so. Clarke (2013, p. 80), on the other hand, points out that the domestic tasks may even provide valuable training and experience in operating in an urban terrain in close interaction with civilians - skills also needed in international counterinsurgency and counter-stabilization missions.

\section{Utility}

From a more general point of view, critics have questioned the utility of deploying armed forces for domestic security tasks, specifically counterterrorism, and argued that in some instances it could be outright counterproductive. Militarizing the handling of terrorism plays into terrorist groups' war rhetoric and inadvertently supports their attempt to fashion themselves as legitimate warriors. Militarizing the response to terrorism, the argument goes, risks boosting extremist groups' recruitment narratives while adding little to society's overall security, as determined terrorists are simply going to avoid heavily protected targets. They also indicate that it might be politically difficult to scale down the level of visible and protective security - what is the exit option with the terrorist threat likely to continue for the foreseeable future? The deployment of soldiers in domestic security roles, it is argued, risks diverting necessary investment in civilian capabilities and agencies, which would represent more appropriate responses to the challenges at hand (Edmunds 2006, p. 1074; Schnabel and Krupanski 2012, p. 56). In the words of Clarke (2013, p. 82), unless the impulse to let the armed forces handle an everwidening array of domestic tasks is checked, European countries may end up with "a very expensive, improperly equipped, and overqualified emergency response instrument instead of a functional military force."

\section{Civil Liberties and Civilian Control}

Deploying military assets and military personnel to assist civilian authorities in coping with terrorism, organized crime, and natural disasters may appear logical, necessary, and undramatic to a majority of citizens. According to critics, however, it 
potentially affects fundamental civil liberties and crucial balances between armed forces and civilian democratic authority. Around the year 2000 scholars debated the tension between combating crime and protecting civil rights after demonstrations had turned violent during summits in Prague, Gothenburg, and other European cities (Flyghed 2002). Then came a wave of terrorism, beginning with 9/11, Madrid (March 11 2,003), London (July 07 2005), and Scandinavia in 2011 (Norway), 2015 (Denmark), and Sweden (2017) not to forget the attacks on London Bridge on June 03 2017. These events changed the political agenda in many Western European countries (Source).

Several scholars point to essential differences between the culture, norms, and worldview of police forces and armed forces. The former "serve, protect, gather evidence, arrest suspects" (Campbell and Campbell 2010, p. 329), whereas the latter "overwhelm, kill, and destroy" (Dunlap 1999, p. 223). Underlining this point, the different skills and attitudes required in an infantry soldier and in police patrol officers are highlighted: Police officers typically need to exercise a higher level of competency when it comes to communication, judgment, persuasion, negotiation, etc. (Campbell and Campbell 2010, p. 343). Since Western democratic states need to maintain order and legitimacy, the core premise of domestic police forces is to apply minimum force, whereas the military, at core, is about winning wars by applying maximum force. The military simply cannot be expected to display the same sensitivity to civil liberties as police forces according to these scholars (Weiss 2011, p. 401). Currently, the empirical evidence on how national armed forces have been trained and prepared for domestic duties and how they have actually performed compared to police forces is largely missing, although research in this field is beginning to emerge (Norheim-Martinsen 2019).

In addition, the involvement of soldiers domestically risks undermining democratic control of the armed forces. Edmunds (2006, p. 1072), highlighting the implicit or explicit encouragement of closer police-military integration in Western countries' external military assistance and security sector reform assistance, argues that the involvement of the armed forces in domestic security historically has led to politization, political meddling, and human rights abuses by the armed forces Even if this may not be evident or imminent in the context of established Western democracies, the argument goes, increased involvement of and dependence on armed forces when it comes to domestic security could gradually upset the balance of power between civilian and military authorities (Kalkman 2019, p. 5).

To sum up, critics have pointed to a range of risks to combat readiness, morale, recruitment, civil liberties, and civilian control and questioned the overall utility of involving armed forces in domestic security and in counterterrorism. Currently, however, the empirical evidence is limited and mixed. More studies are needed to provide clearer answers to how imminent and grave these risks and challenges are and how they apply to countries with different traditions in terms of police-military relations. 


\section{What and How to Study?}

The field is open to enquiries taking a variety of approaches. Besides studies of the drivers and risks of the greater domestic involvement of the armed forces, one could study the impact of different national traditions. In France, for example, there is a tradition for civil-military cooperation in domestic security due to its imperial history (Bosser 2015), while Germany represents a different tradition with a strong aversion against domestic military involvement (Lioe 2011). One may study the implications of "inoculation" as in the German case with the "Polizeibrief" following the atrocities of the Hitler era (or Sweden after soldiers opened fire on workers on strike in Ådalen in 1931). Each country has its own profile rooted in history, and the national cases would be both interesting and useful for students and scholars to investigate. For this purpose, a qualitative historical approach could be applied, looking at news coverage of pivotal events, important political debates, and legislative development from an ideographic angle using newspaper articles, archival sources, and parliamentary proceedings as empirical data (for an example, see Dahlberg and Stevnsborg forthcoming).

Another approach could be to discuss different forms of civil-military cooperation from a social scientific perspective, taking one's point of departure in models and theories. A useful model (Fig. 1), developed by Dr. David Last of the Canadian Royal Military College, explains the relationship between size of force and use of force. Low on the X-and Y-axes we find traditional policing using minimum force and typically being employed in small units, while military forces are placed at the

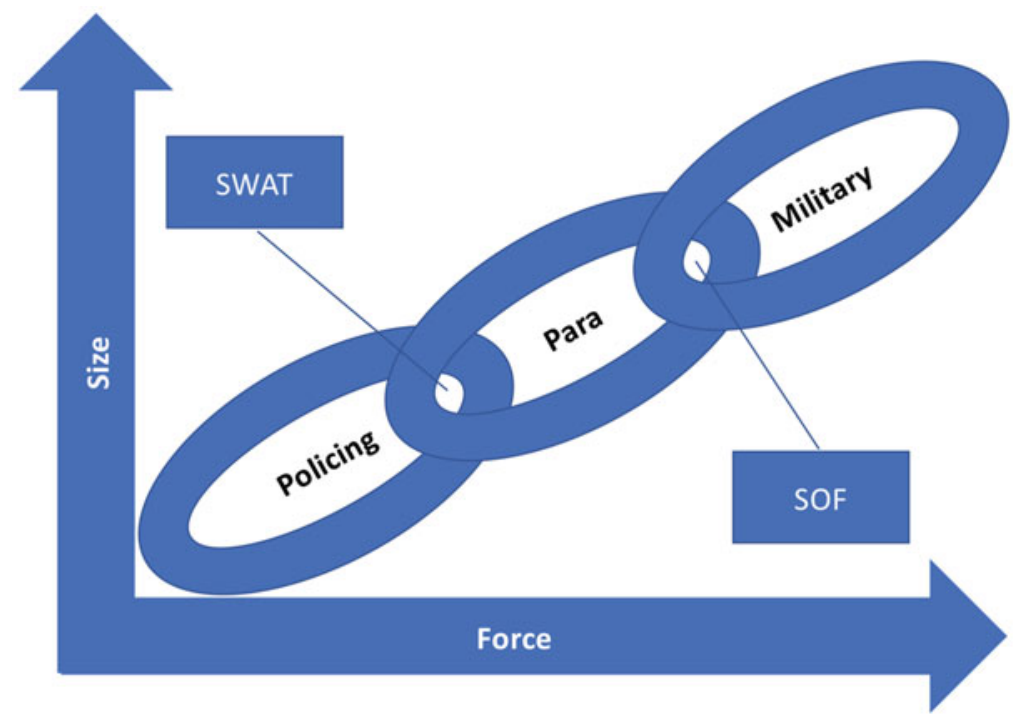

Fig. 1 The relationship between magnitude of force applied (x-axis) and size of force typically used (y-axis). SWAT: Special Weapons and Tactics-units. SOF: Special Operations Forces. Borrowed from Dr. David Last of the Royal Military College of Canada 
other extreme as they apply maximum force organized in larger entities such as companies or brigades to obtain their objectives. Special Weapons and Tactics (SWAT) teams lie between traditional policing and para-military organizations (e.g., gendarmeries or militia), while Special Operations Forces (SOF) overlap para-military and ordinary military forces as they typically operate in smaller groups and use special weapons and tactics, but distinguish themselves from police forces by the application of more violence. This model provides students and scholars with a basic framework for a nomothetic discussion of different types of institutions involved in domestic security.

Studies of how civilian and military forces cooperate at the operational level are also highly relevant. The response to the terrorist attacks on the concert hall Bataclan in Paris highlights one challenge. As related above, the soldiers rejected the police officers' request to help move into the concert hall, arguing that they were not authorized to do so (Schack 2016, p. 4). What happens when armed forces rooted in military planning regimes have to respond quickly to unforeseen incidents? Such studies could focus on different Rules of Engagement, operational concepts/doctrines, and competing forms of Command and Control structures but should also be concerned with differences in organizational cultures in a broader perspective.

As mentioned above, the average citizen of Western democracies trusts the armed forces. Civilian and democratic control of the armed forces seems like a fact of life and is rarely questioned or even debated. Scholars within the field civil-military relations - an interdisciplinary field spanning political science, law, sociology, and history and concerned with studying the role and power distribution between military and civilian authorities and organizations - would almost certainly regard this as misplaced complacency. They would emphasize the need to continuously pay attention to how the armed forces are controlled and what roles they perform (Foster 2016, p. 34; Feaver 1996; Owens 2010, p. 2). More research on the public perception of "soldiers in the streets" is needed, including broad quantitative surveys as well as smaller qualitative studies aimed at specific groups or individuals.

Tracing the concept of constabularization back to Janowitz (1960), one could also point to policing in international peacekeeping missions as a related topic for study. An early example of the use of military corps for policing was the United States Constabulary, a US Army military gendarmerie force tasked with upholding law and order in occupied Germany 1946-1952 after the collapse of the Third Reich (Kaufman 2017). During the Cold War, the idea of a superpower being able to apply less than maximum force appealed to Janowitz and his followers, and after the end of the bipolar era, this was exactly the task that Western armed forces were given. Peacebuilding and peacekeeping missions in the Balkans in the 1990s and Iraq and Afghanistan in the following decades became the core business of the United States and its allies. This novel focus on civil-military interaction and the comprehensive approaches required holds the potential for many relevant and interesting studies (Greener and Fish 2011).

A multitude of comparative studies within the field could also be carried out. One universal parameter is the legal requirements for call outs of armed forces across national borders, so studies of how militaries actually can and have been called out 
for domestic security purposes in different countries are highly interesting and relevant. For example, when the Belgian government called out troops for Operation Vigilant Guardian after the 2016 terrorist attacks, the legal framework behind the decision was debated (Clearman 2018). And for comparison it is worth noting that while the Australian Defence Amendment has been updated several times since 2000 to allow the Commonwealth to use military forces in domestic security, the Constitution does not define "domestic violence," which is a prerequisite for callouts, and it could very well be up to the High Court to test the legality of such (Sutton 2017).

\section{Summary}

Since the end of the Cold War, Western armed forces increasingly play a role in domestic security and in supporting national and local police forces. While majorities among politicians and publics appear to accept this trend as necessary and unproblematic, possibly connected to high levels of trust in the armed forces, analysts and scholars have engaged in lively debate over its drivers and desirability (source). As shown above, some scholars regard the increasing role of armed forces in domestic security as a logical development, reflecting new intractable, transnational threats, which cross the boundary between internal and external security, while critics claim that the values, mindsets, skills, tactics, and approaches of soldiers and police officers differ. They argue that the expanding domestic security roles of the armed forces risk undermining combat readiness and morale in the armed forces as well as civil liberties and, ultimately, civilian control of the military.

Currently, the empirical evidence is limited and mixed. The field would benefit from additional research.

An excellent metaphor for the entanglement of civil-military relations has been provided by Didier Bigo who described the unclear boundaries of security tasks as a "Möbius ribbon," the intriguing topology of a two-sided band that has been cut, twisted, and reassembled so it in effect has only one surface and only one boundary. A small creature traveling across this structure will thus move through both domains without ever crossing the boundary between them. This represents vividly the delicate balance between civilian and military use of force in domestic security that students and scholars must navigate and investigate to increase our understanding of their role in society.

\section{Cross-References}

Civil Military Relations: What is the State of the Field?

Civil-Military Relations?

- Military Training, Education and Socialization 


\section{References}

Bigo, D. (2000). When two become one: International and external securitisations in Europe. In Kelstrup \& William (Eds.), International relations theory and the politics of European integration (pp. 171-204). London: Routledge.

Bosser, J.-P. (2015). The French Army, French soil and the security of the French people. Inflexions, 3, 187-190.

Burk, J. (2002). Theories of democratic civil-military relations. Armed Forces \& Society, 29, 17-29.

Campbell, D. J., \& Campbell, K. M. (2010). Soldiers as police officers/police officers as soldiers: Role evolution and revolution in the United States. Armed Forces and Society, 36(2), 327-350.

Chrisafis, A. (2016). Thousands of troops on Paris streets but are they France's new Maginot line? The Guardian, 15 April. https://www.theguardian.com/world/2016/apr/15/paris-attacks-opera tion-sentinelle-soldiers-patrolling-streets-france-safer (accessed 08.05.2020).

Clarke, J. L. (2013). Europe's armed forces in civil security. The Quarterly Journal, 12(2), 69-83.

Clearman, J. (2018). Operation Viligant Guardian en militaire openbare ordehandhaving doorgelicht: de juridische zin en onzin van militairen op straat. Ghent: Ghent University.

Dahlberg, R., \& Stevnsborg, H. (forthcoming). Gendarmeries in Denmark. Scandinavian Journal of Military Studies.

Dunlap, C. J. (1999). The police-ization of the military. Journal of Political and Military Psychology, 27, 217-232.

Edmunds, T. (2006). What are armed forced for? The changing nature of military roles in Europe. International Affairs, 82(6), 1059-1075.

Feaver, P. D. (1996). The civil-military problematique: Huntington, Janowitz, and the question of civilian control. Armed Forces \& Society, 23(2), 149-178.

Fisher, E. (2011). Disaster response: The role of a humanitarian military. Army Technology, 25 July 2011. https://www.army-technology.com/features/feature125223/. Accessed 21 Jan 2020.

Flyghed, J. (2002). Normalising the exceptional: The case of political violence. Policing and Society, 13(1), 23-41.

Foster, G. (2016). Civil-military relations on trial: Through the eyes of tomorrow's military leaders. The RUSI Journal, 161(4), 34-41.

Gobinet, P. (2008). The gendarmerie alternative: Is there a case for the existence of police organisations with military status in the twenty-first century European security apparatus? International Journal of Police Science and Management, 10(4), 448-463.

Huntington, S. (1957). The solider and the state: The theory and politics of civil-military relations. Cambridge, MA: Harvard University Press.

Janowitz, M. (1960). The professional soldier: A social and political portrait. New York: Free Press.

Johansen, A. (2017). Future trends in historical research on policing: Towards global and interdisciplinary perspectives. Crime, History \& Societies, 2(21), 113-121.

Johnson, C. (2018). Trust in the military exceeds trust in other institutions in Western Europe and U.S. Pew Research Center. http://www.pewresearch.org/fact-tank/2018/09/04/trust-in-the-mili tary-exceeds-trust-in-other-institutions-in-western-europe-and-u-s/. Accessed 3 May 2019.

Kalkman, J. (2019). The expanding domestic role of western armed forces and its implications. Journal of Homeland Security and Emergency Management, 2019, 1-7.

Kaufman, D. A. (2017). Mobility, vigilance, justice: The U.S. Constabulary Forces in Germany, 1946-1952. National Museum of the United States Army. https://armyhistory.org/mobilityvigilance-justice-the-u-s-constabulary-forces-in-germany-1946-1952/. Accessed 2 Feb 2020.

Marten, K. (2019). Russia's use of semi-state security forces: The case of the Wagner group. PostSoviet Affairs, 35(3), 181-204.

McCrie, R. D. (2006). A history of security. In M. Gill (Ed.), The handbook of security. New York: Palgrave Macmillan.

Nielsen, J. B., \& Domino, S. (2018, 23. January). Pape om terrortruslen efter kalifatets fald: Vi skal vænne os til soldater I gaderne. Berlingske, 1 sektion, p. 3. 
Norheim-Martinsen, P. M. (Ed.). (2019). Det Nye Totalforsvaret. Oslo: Gyldendal.

Owens, M. T. (2010). (online publication 2017)). Oxford research encyclopedia of international studies. Civil-military relations. Cambridge: Oxford University Press.

Schack, M. (2016). Soldater i Europas gader. Et komparativt studie af de militcere bidrag til national terrorbekcempelse i udvalgte europaiske lande. Copenhagen: Center for Militære Studier.

Schnabel, A., \& Krupanski, M. (2012). Mapping evolving internal roles of the armed forces. SSR paper 7. Geneva: The Geneva Centre for the Democratic Control of Armed Forces (DCAF).

Stevnsborg, H. (2018). Udansk og/eller paradigmeskift? Om forsvarets bidrag til politiet. Ugeskrift for Retsvaesen, 34, 185-191.

Suro, R. (1998, 13. November). Report: US 'failures' lead to border death. The Washington Post, A03.

Sutton, J. (2017). The increasing convergence of the role and function of the ADF and civil police. Australian Defence Force Journal, 202, 37-44.

Wass de Cwege, H. (2006). On policing the frontiers of freedom. Army, 56(7), 14-22.

Weiss, T. (2011). The blurring border between the police and the military: A debate without foundations. Cooperation and Conflict, 46(3), 396-405.

\section{Further Reading}

Easton, M., den Boer, M., \& Janssens, J. (Eds.). (2010). Blurring military and police roles. The Hague: Eleven International Publishing.

Greener, B. K., \& Fish, W. J. (2011). Situating police and military in contemporary peace operations. Civil-Military Occasional Papers, 3.

https://content.sciendo.com/view/journals/jms/8/2019/article-p16.xml

Lioe, K. E. (2011). Armed forces in law enforcement operations. Berlin-Heidelberg: Springer.

Open Access This chapter is licensed under the terms of the Creative Commons Attribution 4.0 International License (http://creativecommons.org/licenses/by/4.0/), which permits use, sharing, adaptation, distribution and reproduction in any medium or format, as long as you give appropriate credit to the original author(s) and the source, provide a link to the Creative Commons license and indicate if changes were made.

The images or other third party material in this chapter are included in the chapter's Creative Commons license, unless indicated otherwise in a credit line to the material. If material is not included in the chapter's Creative Commons license and your intended use is not permitted by statutory regulation or exceeds the permitted use, you will need to obtain permission directly from the copyright holder. 